\title{
Chromosome Transfer in Proteus mirabilis Mediated by a Hybrid Plasmid
}

\author{
By J. N. COETZEE \\ Department of Microbiology, University of Pretoria, Republic of South Africa
}

(Received 24 June 1974)

\begin{abstract}
SUMMAR Y
A previously-described fused plasmid, P-lac $\overline{\mathrm{RI} d r d \mathrm{I} 9}$, was found to mediate chromosomal transfer between cells of Proteus mirabilis strain PM5006; PM5006$(P-l a c \overline{\mathrm{RI} d r d \mathrm{I} 9})$ was usually the donor and various auxotrophs of PM5006 resistant to nalidixic acid and/or streptomycin were recipients. The donor was usually counterselected with nalidixic acid and/or high concentrations of streptomycin. Recombination experiments with single markers indicated a 40-fold variation in recombination frequencies for different markers. Mapping double-auxotrophic markers by their gradient of transmission confirmed this variation and placed each of two independent isolates of eight markers in a linkage group his-ser-ura-pyrBtrp-cys-ade-ilv. Some donor markers did not register. Despite low recombination frequencies, interrupted mating experiments showed a polarity of early marker transfer. The segregation of unselected markers confirmed the order of some markers and showed that genetic material passed from the presumptive donor to the recipient. Recipients with two auxotrophic markers which could not be cotransduced by phage $5006 \mathrm{M}$ were converted to prototrophy by conjugation. The plasmid transferred to recipients at high frequency and all recombinants carried it. Recombinants could act as donors in further matings. Recombinants were fully susceptible to phage 5006M, unlike transductants of PM5006 by this phage. Direct involvement of the plasmid was indicated by drastically diminished recombination frequencies in crosses with recipients carrying P-lac as resident. P-lac had previously been shown to reduce the frequency of transfer of the hybrid plasmid to cells harbouring it. The histidine region was the first to register in recipients and recombined at the highest frequency of $5 \times 10^{-6} /$ donor cell. Some temporary association of plasmid and perhaps only the histidine region of the chromosome is favoured as the mechanism of chromosomal transfer. This could explain why not all donor markers could be mapped. Transduction and transformation were excluded as the cause of results.
\end{abstract}

\section{INTRODUCTION}

Dienes (I946, I947) likened the large bodies formed in the demarcation line between opposing swarms of Proteus to zygotes, but 'crossing or segregation' of properties was not observed. Stempen \& Hutchinson (195I) observed fusion of Proteus vulgaris cells: a bud developed at the site of fusion and this grew into a large body which divided or ruptured. It could not be determined whether a hybrid phenotype resulted. Kvittingen (I953) maintained that swarms of Proteus mirabilis and P. vulgaris are sexual forms and obtained fermentation hybrids when different swarms were mixed on agar. This work has not been confirmed. Hutchinson \& Medill (I954) and Hutchinson \& Stempen (I954), with the use of various spontaneously arising markers, could not demonstrate recombination between strains of $P$. mirabilis, $P$. vulgaris or $P$. morganii. Proteus spp. can conjugate - they may receive and transfer a variety of plasmids both intra- and extragenerically (see Coetzee, 
I972) - but it is generally accepted that chromosomal transfer has not been demonstrated in Proteus.

Certain R factors may mediate transfer of the Escherichia coli chromosome (Sugino \& Hirota, 1962; Watanabe \& Ogata, 1966; Cooke \& Meynell, 1969; Meynell \& Cooke, 1969; Moody \& Runge, I972; Moody \& Hayes, 1972; Hirota, Fujii \& Nishimura, 1966; Nishimura, Nishimura \& Caro, 1973) and the chromosome of Pseudomonas aeruginosa has also been transferred by $\mathrm{R}$ factors (Stanisich \& Holloway, 197I).

The plasmid P-lac $\overline{\mathrm{RI} d r d \mathrm{I} 9}$ investigated here, is a hybrid (Coetzee, 1974) produced by transduction of RIdrdI9 (Meynell \& Datta, 1967) with vector phage PL25 (Coetzee, Smit \& Prozesky, 1966) to Providence strain P29 carrying P-lac (Falkow, Wohlhieter, Citarella \& Baron, 1964; Wohlhieter, Falkow, Citarella \& Baron, 1964) as resident. The hybrid transmits to various $P$. mirabilis, Providence and $E$. coli strains at a frequency of about $10^{-1} /$ donor cell. Both P-lac (Falkow et al. 1964) and R IdrdI9 (Pearce \& Meynell, I968; Meynell \& Ewins, 1973) can transfer the E. coli chromosome.

\section{METHODS}

Bacteria, plasmids and phages. These are listed in Table I.

Media. Nutrient broth was Oxoid No. 2 code CM 67; nutrient agar was the same solidified with $\mathrm{I} \cdot 2 \%(\mathrm{w} / \mathrm{v})$ Difco agar. MacConkey agar was Difco. Minimal medium was that of Grabow \& Smit (1967). This medium was supplemented with amino acids (20 $\mu \mathrm{g} / \mathrm{ml})$ to suit auxotrophic strains when necessary. Incubation temperature was $37^{\circ} \mathrm{C}$ and media were brought to that temperature before inoculation.

Antibacterial drugs. The minimal medium contained streptomycin $(7000 \mu \mathrm{g} / \mathrm{ml})$ or nalidixic acid $(50 \mu \mathrm{g} / \mathrm{ml})$ or both drugs to counterselect donors in some mating experiments. Ampicillin and kanamycin $(50 \mu \mathrm{g} / \mathrm{ml})$ were added to MacConkey agar when necessary. Rifampin was used at $1000 \mu \mathrm{g} / \mathrm{ml}$.

Phage absorption and transduction. Adsorption of phages to donor and recipient strains was determined by the method of Coetzee(196I). Transduction was performed by the methods of Coetzee, Datta, Hedges \& Appelbaum (1973) except that the multiplicity of phage input was reduced to about I.

Transfer of plasmids from Escherichia coli $\mathrm{J62}-\mathrm{I}$ to strains of PM5006. This was accomplished by the method of Coetzee et al. (I973) with the use of tetracycline to counterselect the E. coli strain.

Transfer of P-lac $\overline{R I d r d I 9}$ from strains of PM5006 to J62rif-r. This was done as above with contraselection of the donor with rifampin.

Bacterial conjugation. An overnight broth culture of donor was diluted $\mathrm{I}: \mathrm{Io}$ in broth and incubated for $2 \mathrm{~h}$. The mating mixture contained I ml donor culture, $4.5 \mathrm{ml}$ of an overnight broth culture of recipient and $4.5 \mathrm{ml}$ broth. Controls lacked the donor or recipient and in some experiments neither culture carried the plasmid. In preliminary experiments $4 \mu \mathrm{g}$ deoxyribonuclease I (Sigma)/ml were added at the time of mixing. The mixture was incubated for $2 \mathrm{~h}$. Samples of the mating mixture and controls were then filtered through Millipore membranes (Sartorius, Göttingen, Germany), washed with a large excess of sterile warm saline, and the membranes then placed on appropriate minimal media to detect prototrophy and on selective MacConkey agar for determination of extrachromosomal plasmid transfer. Minimal media were incubated for $48 \mathrm{~h}$ and MacConkey media for $24 \mathrm{~h}$ before results were read. Other samples were also treated with $0 \cdot$ I vol. chloroform and after evaporation of the chloroform the supernatants were titrated on PM5006 for phage detection. 
Table I. Bacteria, plasmids and phage

Bacteria

PM5006

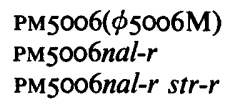

Auxotrophs of PM5006

UP I

UP2

UP3

UP4

UP5

UP6

UP7

UP8

UP9

UPIO

UPI I

UP12

UPI 3

UPI 4

UPI 5

UPI6

UPI7

UPI 8

UPI9

UP2O

UP2 I

UP22

UP23

UP24

Escherichia coli $\mathrm{K} \mathrm{I} 2$ J62-I

s62rif-r

Plasmids and hosts

PM5006(P-lac)

PM5006(RIdrdi9)

PM5006(P-lac $\overline{\mathrm{RI} d r d \mathrm{I9})}$ *

J62-I(P-lac)

J62-I (P-lac $\overline{\mathrm{RI} d r d \mathrm{I} 9}) *$

Phage

\section{Properties}

Recipient for generalized transducing phage 34.PMI3. Restricts and modifies phage 34.PMI $T$ resistant. Cryptically lysogenic for generalized transducing phage 5006M. Susceptible to many Proteus bacteriophage tail-like bacteriocins but not bacteriocinogenic

PM5006 lysogenized with phage $5006 \mathrm{M}$ Nalidixic acid resistant mutant of PM5006 Streptomycin resistant mutant of PM5006nal-r

$\operatorname{trp-I}$

trp-I nal-r mutant of UP I

his-I nal-r mutant of PM5006nal-r pyrBI nal-r mutant of PM5006nal-r arg-I nal-r mutant of PM5006nal-r his-I ser-2 nal-r mutant of UP3 tyr-I str-r mutant of PM5006str-r leu-I str-r mutant of PM5006str-r pyrBI trp-2 nal-r mutant of UP4 met-I nal-r str-r mutant of PM5006 nal-r str-r ilv-I mutant of PM5006nal-r ade-I nal-r mutant of PM5006nal-r cys-I nal-r mutant of PM5006nal-r ura-I str-r mutant of PM5006str-r ser-I nal-r str-r mutant of PM5006nal-r str-r his-I nal-r str-r mutant of UP3 his-I pyrB2 nal-r str-r mutant of UPI 6 his-I ser-2 nal-r str-r mutant of UPI 6 his-I ser-2 ura-3 nal-r str-r mutant of UPI 8 his-I ura-2 nal-r str-r mutant of UPI 6 his-I trp-3 nal-r str-r mutant of UPI 6 his-I cys-2 nal-r str-r mutant of UPI 6 his-I ade-2 nal-r str-r mutant of UPI 6 his-I ilv-2 nal-r str-r mutant of UPI 6

Nalidixic acid resistant mutant of $\mathrm{J62}$, an $\mathrm{F}^{-}$lac pro his trp strain

Spontaneous mutant of $\mathrm{s} 62$ resistant to I000 $\mu \mathrm{g}$ rifampin $/ \mathrm{ml}$

$\operatorname{lac}^{+}$

ACKSSu

ACKSSu $l a c^{+}$. Derived from P29str-r(Plac $\overline{\mathrm{R} I d r d 19}$ )* by conjugal transmission of the fused plasmid to J62-I and then to PM5006 with contraselection for $\mathrm{J} 62-\mathrm{I}$ with $\mathrm{T}$. Fully susceptible to phage $5006 \mathrm{M}$ $\mathrm{lac}^{+}$

ACKSSu $\mathrm{lac}^{+}$
Reference(s)

Coetzee, De Klerk \&

Coetzee (1968);

Coetzee \& Smit (1970);

Niemand (I97I);

Krizsanovich (1973);

Coetzee (1974; unpublished)

Coetzee (unpublished)

Coetzee (1974)

Coetzee (unpublished)

Auxotrophs: $N$-methyl- $N^{\prime}-$ nitro- $N$-nitrosoguanidine induced. Drug resistance: spontaneous selected mutants (Coetzee, unpublished)

Clowes \& Hayes (1968);

Coetzee, Datta, Hedges \&

Appelbaum (1973)

Coetzee (unpublished)

Coetzee (1974)

Coetzee (I974)

Coetzee (1974;

unpublished)

Coetzee (unpublished)

Coetzee (unpublished)

$5006 \mathrm{M}$

Serologically and morphologically identical to phage 34. Generalized transducing for PMI3, PM5006. Converts hosts to non-adsorption of phages $34,5006 \mathrm{M}$
Coetzee \& Sacks (1960);

Krizsanovich (1973);

Coetzee (unpublished)

A, ampicillin; C, chloramphenicol; K, kanamycin; S, streptomycin; Su, sulphonamide; T, tetracycline.

* Superior line indicates transduced $\mathrm{R}$ factor. 
Table 2. Recombination experiments with three different donors

\begin{tabular}{|c|c|c|c|c|c|}
\hline \multirow[b]{2}{*}{ Experiment no. } & \multirow[b]{2}{*}{ Recipient } & \multirow[b]{2}{*}{$\begin{array}{l}\text { Selected } \\
\text { donor } \\
\text { marker(s) }\end{array}$} & \multicolumn{3}{|c|}{ No. prototrophs $/ 10^{8}$ donor cells* } \\
\hline & & & $\begin{array}{c}\text { PM5006- } \\
\text { (P-lacR Idrd I9) }\end{array}$ & $\begin{array}{l}\text { PM5006- } \\
(\mathrm{P}-l a c)\end{array}$ & $\begin{array}{l}\text { PM5006- } \\
\text { (RIdrdI9) }\end{array}$ \\
\hline I & UP3 & his-I & 5 I I & o & 0 \\
\hline 2 & UPI 5 & $\operatorname{ser}-I$ & 301 & o & 0 \\
\hline 3 & UP I 4 & ura-I & 219 & 0 & 0 \\
\hline 4 & UP4 & pyrBI & I I I & 0 & 0 \\
\hline 5 & UP2 & $\operatorname{trp-I}$ & 53 & 0 & 0 \\
\hline 6 & UPI 3 & cys $-I$ & 30 & 0 & 0 \\
\hline 7 & UPI 2 & ade-I & 19 & 0 & 0 \\
\hline 8 & UPII & $i l v-I$ & 5 & 0 & 0 \\
\hline 9 & UPI 7 & his-I pyrB2 & 96 & 0 & 0 \\
\hline IO & UP9 & pyrBI trp-2 & 70 & 0 & 0 \\
\hline I I & UP6 & his-I ser-2 & 480 & 0 & 0 \\
\hline I 2 & UP8 & leu-I & 0 & 0 & 0 \\
\hline 13 & UP5 & $\arg -I$ & 0 & 0 & 0 \\
\hline 14 & UPIO & met-I & 0 & 0 & 0 \\
\hline I 5 & UP7 & $t y r-I$ & 0 & 0 & 0 \\
\hline 16 & UPI 6 & $h i s-I$ & 519 & 0 & 0 \\
\hline
\end{tabular}

* Average of four experiments. Mating mixtures and controls were constituted as described in text. One $\mathrm{ml}$ of the mixtures was filtered and the membrane placed on minimal medium containing streptomycin and/or nalidixic acid.

Recombination frequency was expressed with reference to the count of donor bacteria in the mating mixture at the time of mixing. To determine whether intact viable cells were necessary for recombinant formation and to further exclude possibilities of transduction and also transformation (Sugino \& Hirota, 1962) either of the parent cultures (in separate experiments) was sterilized by treatment with $\mathrm{O} \cdot \mathrm{I}$ vol. chloroform shortly before constituting the mating mixture. The chloroform was evaporated by passing sterile air through the suspension at $37^{\circ} \mathrm{C}$ and viability was tested by plating samples on MacConkey agar.

Interrupted mating. To $\mathrm{I} 8 \mathrm{ml}$ of a recipient culture in a $300 \mathrm{ml}$ Erlenmeyer flask, $4 \mathrm{ml}$ of donor (prepared as above) were carefully added at time zero, and incubated in a water bath for mating pairs to form. At $5 \mathrm{~min}, 200 \mathrm{ml}$ warm broth were gently added. At intervals, Io $\mathrm{ml}$ samples were carefully removed and mating pairs rudely separated by violent agitation in an MSE homogenizer for I min. The container of the homogenizer was then rinsed with a total of $40 \mathrm{ml}$ warm saline $(0.85 \%, \mathrm{w} / \mathrm{v}, \mathrm{NaCl})$ and samples of this saline suspension immediately filtered through Millipore membranes. The membranes with impinged cells were incubated on minimal medium. Other samples, appropriately diluted, were plated on MacConkey agar containing ampicillin and kanamycin to detect plasmid transfer.

Unselected marker analysis. The clones were purified on the same agar. A single colony was then emulsified in $0.5 \mathrm{ml}$ saline and loopfuls spotted on selective and control media.

Segregation studies. Suitable dilutions of overnight broth cultures of purified his $^{+}$recombinant clones were plated on MacConkey agar. After overnight incubation pale colonies were plated on this agar containing ampicillin and kanamycin and also on minimal medium. 
Table 3. Gradient of transmission of markers in relation to his $^{+}$recombinants in the same cross

Three $\mathrm{ml}$ of the mating mixture were filtered and the membranes placed on minimal media supple-
mented with histidine for the selected donor marker. An equal volume of the mating mixture was
filtered and the membrane placed on minimal media appropriately supplemented for detection of
histidine recombinants in the same cross. Minimal media contained nalidixic acid and streptomycin.

\begin{tabular}{cccc} 
Donor & Recipient & $\begin{array}{c}\text { Donor } \\
\text { marker }\end{array}$ & $\begin{array}{c}\text { Recombinants/ } \\
\text { IO }^{3} \text { his }^{+*}\end{array}$ \\
\cline { 2 - 3 } & UPI8 & ser-2 & 790 \\
& UP20 & ura-2 & 522 \\
UPI7 & pyrB2 & $3 \mathrm{II}$ \\
& UP2I & trp-3 & 190 \\
UP22 & cys-2 & 150 \\
& UP23 & ade-2 & 56 \\
& UP24 & ilv-2 & 30
\end{tabular}

* Average of three experiments.

\section{RESULTS}

Recombination experiments with donor PM5006(P-lac $\overline{R \mathrm{I} d r d \mathrm{I9}})$

Initial observations are presented in Table 2. A variation of up to 40 -fold in recombination frequency for inheritance of particular donor markers was encountered and could suggest polarity of marker transfer. Donor markers leu-I, arg-I, met-I, tyr-I did not register and work with these markers was abandoned. Recipient controls never had more than three colonies per plate and donor controls never had growth. Chloroform-treated supernatants of donor or recipient cultures never formed plaques on PM5006 and all of hundreds of recombinants tested plated phage 5006M with an efficiency similar to that of PM5006. The addition of deoxyribonuclease to mating mixtures had no effect on results. Chloroform-treated donor and recipient suspensions were sterile, and when mixed with corresponding viable partners only those with viable recipients sometimes had a few colonies which corresponded in number to those of the recipient controls mentioned above. Crosses between different auxotrophs not carrying the plasmid never yielded more colonies than appeared on control plates. The requirement for viability of both parental cultures was in agreement with the findings of Sugino \& Hirota (1962) for R factor-mediated chromosome transfer in E. coli and differed from the F-mediated $E$. coli (Hayes, 1952) and Vibrio cholerae systems(Bhaskaran \& Iyer, I96I) where viability of donor bacteria was not essential. However, the bactericidal agents employed differed. Table 2 also indicates that recombinants were not obtained with PM5006(P-lac) or PM5006(RIdrdI9) and experiments with these donors were discontinued. With the availability of double auxotrophic strains each derived from mutant UPI 6 bearing the his marker which appeared to recombine at the highest frequency $\left(5 \times 10^{-6} /\right.$ donor cell), attempts were made to refine some of the results in Table 2. With these strains as recipients the number of recombinants for the other marker could be compared with the his recombinants in the same cross by appropriate selection. Results of this gradient-of-transmission mapping (Loutit, 1969) are presented in Table 3. Unlike ColI-mediated chromosomal transfer in Salmonella typhimurium (Ozeki \& Howarth, 196I) and E. coli (Moody \& Runge, 1972) the relative number of recombinants for different markers varied from 790 to 30 . Comparison with results presented in Table 2 showed that the relative frequency of recombination placed these independently-isolated mutants $\operatorname{ser}-2, u r a-2, \operatorname{pyr} B 2, \operatorname{trp}-2, \operatorname{cys}-2$, ade-2, ilv-2 in the same order. The frequency of transfer of the plasmid was $\mathrm{I} \times \mathrm{IO}^{-1} /$ donor cell and exceeded all 
Table 4. Cross between UP9 and UPI9: segregation of unselected markers

Three $\mathrm{ml}$ volumes of mating mixtures were filtered and membranes placed on appropriately supplemented minimal media.

\begin{tabular}{|c|c|c|c|c|c|c|c|c|}
\hline \multicolumn{6}{|c|}{ Pattern of segregation } & \multicolumn{3}{|c|}{ Recombinants } \\
\hline his & ser & ura & str & pyr $B$ & $\operatorname{trp}$ & Supplement added to minimal medium & No. & rcentage \\
\hline 0 & 0 & $\mathbf{S}$ & 0 & 0 & 0 & Serine, histidine & 20 & 12 \\
\hline 0 & I & $\mathbf{S}$ & 0 & 0 & 0 & & 8 & 5 \\
\hline I & I & $\mathbf{S}$ & 0 & 0 & 0 & & I3I & 80 \\
\hline I & 0 & $\mathbf{S}$ & 0 & 0 & 0 & & 3 & 2 \\
\hline 0 & I & $\mathbf{S}$ & 0 & $\mathbf{I}$ & 0 & & 2 & $\mathbf{I}$ \\
\hline $\mathbf{I}$ & I & $\mathbf{S}$ & 0 & o & $\mathbf{I}$ & Serine, histidine, tryptophan & 0 & o \\
\hline $\mathbf{I}$ & I & $\mathbf{S}$ & 0 & 0 & o & & 55 & IOO \\
\hline I & $\mathbf{S}$ & $\mathbf{I}$ & 0 & 0 & 0 & Uracil, histidine & 30 & 33 \\
\hline $\mathbf{I}$ & $\mathbf{S}$ & o & 0 & o & 0 & & 60 & 67 \\
\hline I & $\mathbf{S}$ & I & 0 & I & 0 & Uracil, arginine, histidine & 6 & 5 \\
\hline I & $\mathbf{S}$ & $\mathbf{I}$ & 0 & 0 & 0 & & $5 \mathrm{I}$ & 39 \\
\hline I & $\mathbf{S}$ & o & 0 & 0 & 0 & & 74 & 56 \\
\hline $\mathbf{S}$ & I & I & 0 & 0 & 0 & Serine, uracil & 29 & 25 \\
\hline $\mathbf{S}$ & I & 0 & 0 & 0 & 0 & & 68 & 60 \\
\hline $\mathbf{S}$ & 0 & 0 & 0 & 0 & 0 & & 17 & 15 \\
\hline
\end{tabular}

$\mathrm{UP9}=\mathrm{PM} 5006$ pyrBI trp-2 nal-r(P-lacR IdrdI9) $;$ UPI9 = PM5006 his-1 ser-2 ura-3 nal-r str-r. I, Allele from donor; o, allele from recipient; $\mathrm{S}$, donor allele selected.

other markers. Many minimal-medium plates which bore recombinant clones from different crosses were replicated to ampicillin-kanamycin-MacConkey agar: all recombinants were $\mathrm{lac}^{+}$and drug resistant, and all clones tested transmitted the plasmid conjugally at the usual high frequency to $E$. coli strain $\mathrm{J} 62$ rif-r. Similar situations exist in $E$. coli $\mathrm{F}^{+} \times \mathrm{F}^{-}$ matings (Hayes, 1953) and in the $V$. cholerae conjugation system (Bhaskaran, 1960), where all recombinants possessed the fertility factor concerned. Also, with ColV2 (Macfarren \& Clowes, I967- and R Idrd I9 (Pearce \& Meynell, 1968)-mediated transfer of the E. coli chromosome, practically all recombinants received the corresponding plasmid. In a Pseudomonas aeruginosa system the number of recombinants which had received the sex factor FP varied from 0 to $7 \mathrm{I} \%$ in various crosses (Holloway \& Fargie, 1960).

All of five independently isolated his mutants of PM5006nal-r str-r were sired to prototrophy by PM5006(P-lac $\overline{\mathrm{RI} d r d \mathrm{I} 9}$ ) at the same frequency as indicated in Table 2 (results not shown) and the possibility was entertained that P-lac $\overline{\mathrm{RI} d r d \mathrm{I} 9}$ carried genes effecting the synthesis of histidine in the same way that Ps. aeruginosa sex factor $\mathrm{FP}_{39}$ possesses the property for leucine biosynthesis (Pemberton \& Holloway, 1973). It was considered because of the higher frequency of transmission of these genes (Table 2, experiments I and I6). This was refuted however by the fact that many more recipients became $l a c^{+}$and drug resistant than histidine independent. Also screening of about 5000 colonies each from six independentlyisolated his $^{+}$recombinants yielded o, 3, 5, 7, 8 and 8 segregants, respectively, which had lost all markers of the plasmid but remained his $^{+}$.

Recombinants from experiments I and 4 (Table 2 ) could sire strain UPI 7 in recombination experiments (not shown) with selection for prototrophy on streptomycin minimal medium. This result could influence recombination frequencies derived from prolonged mating experiments.

The plasmid was readily transferred from $\mathrm{J} 62-\mathrm{I}(\mathrm{P}-\mathrm{lac} \overline{\mathrm{RI} d r d \mathrm{I} 9})$ to auxotrophs of PM5006 
Table 5. Linkage of distal markers to ura-I expressed as no. prototrophic recombinants of selected marker which have incorporated ura-I

Three ml volumes of mating mixtures were filtered and the membranes placed on minimal media containing nalidixic acid and supplemented with uracil.

$\begin{array}{ccccc}\text { Donor } & \text { Recipient } & \begin{array}{c}\text { Selected } \\ \text { recipient } \\ \text { marker }\end{array} & \begin{array}{c}\text { Unselected } \\ \text { donor } \\ \text { marker }\end{array} & \begin{array}{c}\text { Double } \\ \text { recombinants* } \\ (\%)\end{array} \\ \text { UPI4(P-lacRIdrdI9) } & \text { UP4 } & \text { pyrBI } & \text { ura-I } & 4 \text { I } \\ & \text { UP2 } & \text { trp-I } & \text { ura-I } & 29 \\ & \text { UPI3 } & \text { cys-I } & \text { ura-I } & 24 \\ & \text { UPI2 } & \text { ade-I } & \text { ura-I } & \text { I8 } \\ & \text { UPI I } & i l v-I & \text { ura-I } & \text { I2 }\end{array}$

* About 90 recombinants, each from two experiments, were examined for each cross.

Table 6. Cross between UP9 and UPI I : segregation of unselected markers

Three $\mathrm{ml}$ volumes of the mating mixture were filtered and the membranes placed on minimal medium or this medium appropriately supplemented.

\begin{tabular}{|c|c|c|c|c|}
\hline \multicolumn{5}{|c|}{ Pattern of segregation } \\
\hline nal & pyr & $\operatorname{trp}$ & $i l v$ & str \\
\hline 0 & 0 & 0 & $\mathbf{S}$ & 0 \\
\hline I & 0 & 0 & $\mathbf{S}$ & 0 \\
\hline 0 & 0 & I & $\mathbf{S}$ & 0 \\
\hline 0 & 0 & 0 & $\mathbf{S}$ & 0 \\
\hline I & 0 & 0 & $\mathbf{S}$ & 0 \\
\hline 0 & $\mathbf{I}$ & 0 & $\mathbf{S}$ & 0 \\
\hline 0 & 0 & 0 & $\mathbf{S}$ & 0 \\
\hline
\end{tabular}

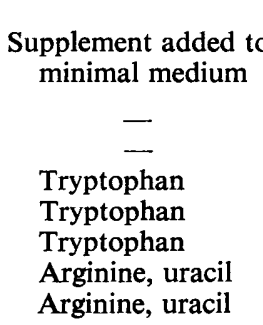

\begin{tabular}{|c|c|}
\hline \multicolumn{2}{|c|}{ Recombinants } \\
\hline No. & Percentage \\
\hline 44 & 9I \\
\hline 4 & 9 \\
\hline 46 & 77 \\
\hline I I & 18 \\
\hline 3 & 5 \\
\hline 13 & 14 \\
\hline $8 \mathrm{I}$ & 86 \\
\hline
\end{tabular}

$\mathrm{UP9}=\mathrm{PM5006pyrBI}$ trp-2 nal-r(P-lacR $\overline{\mathrm{I} d r d \mathrm{I9}})$; UPI I = PM5006ilv-I str-r. I, Allele from donor; 0, allele from recipient; $\mathrm{S}$, donor allele selected.

without affecting chromosomal markers of the strains. Segregations of unselected markers in a mating between strains UP9 and UPI9 are presented in Table 4. Most of the alleles were those of the non-plasmid bearing parent (also see Table 6) indicating that transfer occurred to the latter organism. No recombinants of the donor allele of str were encountered. It appeared that when ser or ura was selected the transferred chromosome hardly ever extended beyond this region and str, trp loci of the donor never registered. Pearce \& Meynell (I968) encountered similar phenomena with $\mathrm{RI} d r d \mathrm{I}$ 9-mediated chromosomal transfer in $E$. coli. The relative numbers of recombinants for his, ser and ura may mean that these markers were transferred in that order. Support for a fixed gradient of transfer in which his regularly preceded ura was provided by the finding that amongst recombinants selected for the distal marker ura, $82 \%$ were also is $^{+}$, whereas only $25 \%$ of recombinants selected for his ${ }^{+}$ received $u_{\mathrm{ra}}{ }^{+}$.

Table 5 presents results of attempts to determine linkage between distal markers and the proximal ura- $I$ locus. Taking the number of recombinants between the two markers listed as a measure of linkage, it was seen that markers $p y r B I$ trp-I cys-I ade-I ilv-I are linked to the ura- $I$ marker in the order predicted by results listed in Tables 2 and 3. The simplest conclusion to be drawn from the data is that at least eight of the loci are on one linkage group and the probable order is his-ser-ura-pyrB-trp-cys-ade-ilv. Attempts were made to locate str and nal loci by mating strains bearing late markers (Table 6). A few nal recombinants were 


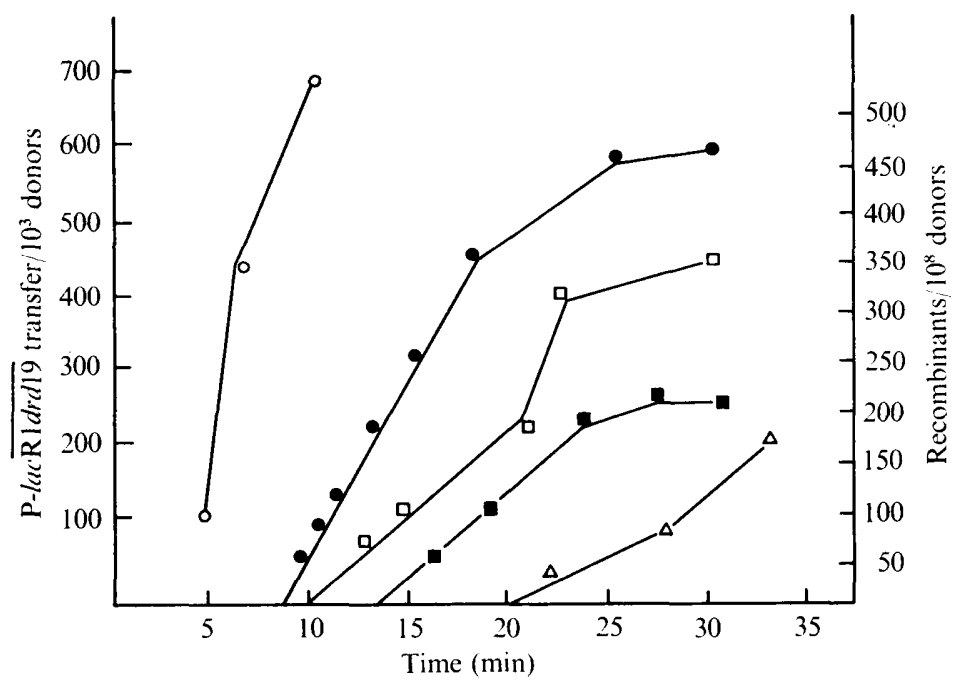

Fig. I. Time of entry of donor markers. The crosses were PM5006(P-lac $\left.\overline{\mathrm{RI}_{\text {Idrd19}}}\right)$ with UPI9 and UP I7. Mating mixtures were constituted for interrupted matings as described in the text. Samples were removed at intervals, blended and filtered. Membranes from the first cross were placed on minimal medium supplemented for selection of one of the markers. Membranes from the second cross were placed on unsupplemented minimal medium. All minimal media contained streptomycin and nalidixic acid. For plasmid transfer, membranes were placed on MacConkey agar for 60 min before transfer to agar containing ampicillin and kanamycin. O, Plasmid; $\bullet$, his-I; $\square$, ser-2; $\square$, ura-3; $\triangle$, his-I pyrB2.

found with selection for $i l v-I$, but the absolute numbers of recombinants were low and only suggestive evidence existed for linkage between ilv-I and the nal locus. These experiments also meant that results of recombination experiments reported in Tables 2 and 3 were possibly not distorted by close linkage of selected markers to nal or str loci used for contraselection of donors.

\section{Interrupted mating}

These experiments were done in attempts to confirm the possibility of polarized transfer of markers suggested by the great variation in recombination frequencies presented in Tables 2 and 3. In Fig. I the times of entry of a few markers with relatively high recombination frequencies are shown. Nevertheless, owing to the low recombination frequency of even these markers, the mating mixture was diluted only $\mathrm{I}: 9$ with broth. The probability therefore existed that new mating pairs were formed throughout the experiments. Concentrated parental mixtures were filtered in order to give significant prototroph counts. This raised the possibility that recombination occurred on the membrane during subsequent incubation on minimal agar. Also, Loutit, Pearce \& Marinus (1968) found that, in a Ps. aeruginosa mating system, unless the mating mixture was diluted by at least a factor of $\mathrm{IO}^{-2}$ a delay occurred in the appearance of recombinants which was greater for distal markers. Nevertheless, the order of entry corresponded to that predicted by the results of the gradientof-transmission mapping listed in Table 3 and the segregation studies of Table 4 . Because of objections mentioned above, the times of entry must be regarded as approximate. It was evident that the plasmid P-lac $\overline{\mathrm{RI} d r d \mathrm{I} g}$ entered recipient cells early and at high frequency. Early and rapid transfer of $\mathrm{R} I d r d \mathrm{I} 9$ occurred in $E$. coli crosses mediated by the latter plasmid (Pearce \& Meynell, 1968) and in $\mathrm{FP}^{+} \times \mathrm{FP}^{-}$Ps. aeruginosa conjugation systems the 
Table 7. Crosses between $\mathrm{PM} 6006(P-l a c-\overline{R \mathrm{I} d r d \mathrm{I} 9})$ and recipients with $P$-lac as resident

Experimental conditions were as for Table 2.

\begin{tabular}{|c|c|c|c|}
\hline Donor & Recipient & $\begin{array}{c}\text { Selected } \\
\text { donor } \\
\text { marker }\end{array}$ & $\begin{array}{l}\text { No. proto- } \\
\text { trophs/10 } \\
\text { donor } \\
\text { cells* }\end{array}$ \\
\hline PM5006(P-lacR $\overline{\mathrm{I} d r d \mathrm{I} 9)}$ & $\begin{array}{l}\text { UP3(P-lac) } \\
\text { UP4(P-lac) } \\
\text { UPI4(P-lac) } \\
\text { UPI 5(P-lac) }\end{array}$ & $\begin{array}{l}\text { his-I } \\
\text { pyrBI } \\
\text { ura-I } \\
\text { ser-I }\end{array}$ & $\begin{array}{r}3 \text { I } \\
5 \\
\text { II } \\
22\end{array}$ \\
\hline
\end{tabular}

* Average of two experiments.

factor was also transmitted at maximal frequency soon after conjugation commenced (Stanisich \& Holloway, 1969). The conclusion drawn from these experiments was that a nonrandom temporal entry of the loci on a linear linkage group existed and that the probable order was his, ser, ura. This order was reproducible. The fact that the first marker, his, only registered in recipients after 8 min could mean that undetected markers were preceding it. Another explanation (Pittard, Loutit \& Adelberg, 1963; Pittard \& Adelberg, 1963) is that the delay was caused by interaction between plasmid and chromosome during transfer. Confidence that the polarity of transfer was due to a linear array of markers passing from donor to acceptor was increased by the observation that with the use of strain UPI 7 with markers his-I pyrB2 the appearance of prototrophs on unsupplemented minimal medium was delayed to possibly coincide with the time of entry of the more distal marker pyrBz (see Pemberton \& Holloway, 1972).

\section{Crosses between $\mathrm{PM} 5006(P$-lac $\overline{\mathrm{RI} d r d \mathrm{I} 9})$ and recipients with P-lac as resident}

P-lac was readily transferred conjugally to strains UP3, UP4, UPI4 and UPI 5 by mating with J62-I(P-lac). Results of conjugation experiments done with these exconjugants are presented in Table 7. Comparison with the corresponding experiments of Table 2 showed a marked decrease in recombinant frequency. The recombinants obtained were ampicillin and kanamycin resistant, lactose positive, and had inherited the plasmid as demonstrated by conjugal transfer of all markers to J62rif-r (not shown). Coetzee (1974) demonstrated that $\mathrm{P}-\mathrm{lac} \overline{\mathrm{R} I d r d \mathrm{I} 9}$ registered at very much lower frequencies in cells harbouring P-lac.

\section{Transduction}

Results of transduction experiments are presented in Table 8. The chloroform-sterilized lysate of PM5006nal-r str-r by phage $5006 \mathrm{M}$ had a titre of $5 \times 10^{9}$ plaque-forming units $/ \mathrm{ml}$ on PM5006. The phage transduced PM5006 to nalidixic acid resistance or streptomycin resistance but the markers were not transduced simultaneously. Also, single auxotrophic markers of strains UP6 and UP9 were readily transduced to prototrophy while the double auxotrophs were not similarly converted by the lysate. In contrast, results presented in Table 2 (experiments Io and II) show that these double auxotrophic strains were converted to prototrophy by conjugal recombination. Although the multiplicity of infection was always less than $\mathrm{I} \cdot \mathrm{O}$ and the adsorption period was only $\mathrm{I} 5 \mathrm{~min}$, none of hundreds of transductant clones plated phage $5006 \mathrm{M}$. It was also evident that the lysate did not transduce lysogenized strains. This was a result of lysogenic conversion causing non-adsorption of the phage (Coetzee, unpublished) and was in agreement with findings of Krizsanovich (1973) and 
Table 8. Transduction of markers by phage $5006 \mathrm{M}$

\begin{tabular}{|c|c|c|c|}
\hline Donor lysate & Recipient & $\begin{array}{l}\text { Selected } \\
\text { marker(s) }\end{array}$ & $\begin{array}{c}\text { frequency/adsorbed } \\
\text { plaque-forming } \\
\text { unit }\end{array}$ \\
\hline \multirow[t]{4}{*}{ PM5006nal-r str-r } & PM5006 & $\begin{array}{l}\text { nal-r } \\
\text { str-r } \\
\text { nal-r str-r }\end{array}$ & $\begin{array}{r}5 \times 10^{-7} \\
\mathrm{I} \times 10^{-7} \\
<\mathrm{I} \times 10^{-9}\end{array}$ \\
\hline & PM5006 $(\phi 5006 \mathrm{M})$ & $\begin{array}{l}\text { nal-r } \\
\text { str-r }\end{array}$ & $\begin{array}{l}<\mathrm{I} \times 10^{-9} \\
<\mathrm{I} \times 10^{-9}\end{array}$ \\
\hline & UP6 & $\begin{array}{l}\text { his-I } \\
\text { ser-2 } \\
\text { his-I ser-2 }\end{array}$ & $\begin{array}{r}5 \times 10^{-8} \\
8 \times 10^{-8} \\
<\quad 1 \times 10^{-9}\end{array}$ \\
\hline & UP9 & $\begin{array}{l}\text { pyrBI } \\
\operatorname{trp}-2 \\
\text { pyrBI trp-2 }\end{array}$ & $\begin{array}{r}1 \times 10^{-7} \\
4 \times 10^{-7} \\
<1 \times 10^{-9}\end{array}$ \\
\hline
\end{tabular}

Phage input multiplicity was I. Adsorption was for $15 \mathrm{~min}$ when samples were filtered. For drugresistant markers the membranes were incubated on MacConkey agar for $3 \mathrm{~h}$ before transfer to selective media. For prototrophy, membranes were transferred directly to minimal medium or to this medium appropriately supplemented.

those for the closely related phages 34 and $\mathrm{PMI}_{3}(\phi 34)$ (Coetzee, I96I). It was concluded that stepwise transduction of strains bearing double markers would not occur in recombination experiments should transducing phage have been present.

\section{DISCUSSION}

Proof that the conjugal chromosome transfer system described here was not masquerading under the guise of transduction or transformation has been obtained. The former possibility was excluded by the fact that free phage was never detected in parent cultures or in mating mixtures and that all recombinants were fully phage-susceptible. This has also been substantiated by the finding that lysogenized strains did not absorb phage and therefore excluded serial transduction of markers which could not be co-transduced. Transformation of strains of $P$. mirabilis, including PM5006, under stringent conditions has been described (Van Rensburg, I970, 197I). Only DNA extracted in the cold with a chloroform-amyl alcohol mixture at $\mathrm{pH} \mathrm{8.5}$ was effective and recipient cells had to be in a particular phase of growth. Transformation was excluded here by the demonstration that chloroform-killed donor (or recipient) cultures in mating mixtures did not produce recombinants and that the presence of deoxyribonuclease in mating mixtures had no effect on the outcome of crosses (Sugino \& Hirota, 1962). The presence in single clones of more than one unselected marker from both parents (Table 4) could not be explained on the grounds of spontaneous mutation and was decisive evidence for genetic recombination. Furthermore, large segments of chromosome were involved and this excluded transduction and almost certainly also transformation.

Accepting conjugal chromosomal transfer as the vehicle for the formation of recombinants a number of problems require explanation. The hybrid P-lac $\overline{\mathrm{RI} d r d \mathrm{I} 9}$ carries markers of both parent plasmids but cells harbouring it are not susceptible to phage MS2 which adsorbs to pili produced by RIdrdI9 (Coetzee, I974). P-lac-derived pili have not been demonstrated and phage, specific for strains carrying P-lac, has not been reported. The frequency of conjugal transmission of the fused plasmid equals that of the derepressed $\mathrm{R}$ factor (Coetzee, 
1974). Why the hybrid plasmid and not one or both of the parents mediate chromosomal transfer is not known. Chromosomal mobilization also does not occur in a Proteus 'double' carrying P-lac and RIdrdI9 as separate entities (unpublished). It could mean that particular regions of one or both plasmids now differ as a result of rearrangement in the fused plasmid. Further study of the plasmids concerned and, in particular, segregants of the hybrid (Coetzee, 1974) may help to clarify the position.

There was definite polarity of entry of some markers and this raised the question of the relationship between P-lac $\overline{\mathrm{RI} d r d \mathrm{I} 9}$ and the donor chromosome. The frequency of transfer of the his marker, the first of the chromosomal markers investigated to enter, was reminiscent of the transfer of the $\operatorname{trp}$ region of $E$. coli by R Idrd 9 (Pearce \& Meynell, I968) where it was claimed that the $\mathrm{R}$ factor had a special affinity for that portion of the chromosome. The latter authors as well as Cooke \& Meynell (1969) suggested that this factor alternated frequently between integration near the $\operatorname{trp}$ region and the autonomous state. Moody \& Hayes (1972) also favoured some mode of RI-determined interaction with the bacterial chromosome (see also Evenchik, Stacey \& Hayes, 1969) and maintained that the efficient transfer of the trp region could hardly be explained on the basis of spontaneous fragmentation and passive transfer with the sex factor only providing effective contact, as has been suggested for factor ColI (Clowes \& Moody, I966; see also Edwards \& Meynell, 1969; Clowes, 1972). Participation of P-lac $\overline{\mathrm{RI} d r d \mathrm{I} 9}$ in the process of chromosome transfer was possibly indicated by results given in Table 6 . The decrease in recombinant frequency could be due to entry exclusion and/or incompatibility of the plasmid by the resident P-lac (Coetzee, 1974) but the reason was not investigated.

Further work on the transfer of the E. coli chromosome by P-lac (Falkow et al. 1964) has not been published. Although many copies of P-lac (Wohlhieter et al. I964) and R Idrdi9 (Haapala \& Falkow, 197I) may be present in cells of $P$. mirabilis, the state of the hybrid plasmid in $P$. mirabilis is not known. Some unstable association between the hybrid plasmid and the chromosome, similar to that proposed for RIdrdI9 but with interaction in the histidine region, may be operative in the present system although recombination frequencies were much lower than RIdrdI9-mediated crosses in E. coli (Pearce \& Meynell, I968). This is disturbing, as transfer frequencies of the plasmids involved are similar (Coetzee, 1974), but may mean that affinity of the plasmid for the particular region of the chromosome was less and consequently only a fraction of the donor population was capable of chromosomal transfer (Adelberg \& Burns, 1960). This also explained the high frequency of independent plasmid transfer, but it is not known what relationship exists between the autonomous and possible integrated states of $\mathrm{P}-\mathrm{lac} \overline{\mathrm{RI} d r d \mathrm{I} 9}$. Should it be analogous to the situation in $E$. coli (Adelburg \& Burns, 1960) there would have to be frequent change between states to prevent loss of the autonomous plasmid. In the Ps. aeruginosa mating system, orientated chromosomal transfer has been demonstrated despite the absence of donors which correspond to stable Hfr strains of E. coli (Holloway \& Fargie, 1960; Stanisich \& Holloway, 1969; Pemberton \& Holloway, 1973; Loutit, Marinus \& Pearce, I 968). These authors also favoured unstable associations between sex factors and the Ps. aeruginosa chromosome.

Strain PM5006 was the initial choice for the investigation as, apart from having auxotrophic mutants of this strain resistant to nalidixic acid and streptomycin available, it differs from strain PMI 3 in that liberation of the cryptic phage occurs very rarely - in the course of this investigation phage $5006 \mathrm{M}$ was never detected. Host-controlled restriction and modification systems are operative in various strains of P.mirabilis including PMI 3 and PM5006 (Coetzee \& Smit, 1969, 1970). For this reason the better-characterized arginine (Prozesky, 1968; Prozesky, Grabow, Van der Merwe \& Coetzee, 1973), methionine (Grabow, 1972a) and cysteine 
(Grabow, 1972b) genes of PMI 3 have not yet been employed in the present system (see also Stanisich \& Holloway, 1969).

The fact that the str locus of donors did not register in recipients, even with selection for the most distal marker available, could mean that the donor chromosome proceeded from only one or a few origins and, as a result, not all regions of the chromosome were equally accessible to mapping (see Pemberton \& Holloway, 1973). Certainly, results of mating experiments were not what would be expected if the plasmid had many potential sites of attachment to the Proteus chromosome as appears to be the case with $\mathrm{F}$ and the E. coli chromosome (Jacob \& Wollman, 1956; Broda, 1967). The object of this investigation was to establish the existence of conjugal chromosomal transfer in P. mirabilis. A study of the complexities and niceties of the process (De Haan \& Gross, 1962; Loutit, Pearce \& Marinus, 1968; Pemberton \& Holloway, 1972) was not attempted. It could be that, using different mating conditions, recombination frequencies of markers would be increased with possible extension of the linkage group.

The author is in receipt of grants from the South African Medical Research Council.

\section{REFERENCES}

AdelBerg, E. A. \& BurNs, S. N. (1960). Genetic variation in the sex factor of Escherichia coli. Journal of Bacteriology 79, 321-330.

BHASKARAN, K. (1960). Recombination of characters between mutant stocks of Vibrio cholerae, strain I62. Journal of General Microbiology 23, 47-54.

BHASKARAN, K. \& IYER, S. S. (196I). Genetic recombination in Vibrio cholerae. Nature, London 189, I0301031 .

Broda, P. (1967). The formation of Hfr strains in Escherichia coli KI2. Genetical Research 9, 35-47.

CLowes, R. C. (1972). Molecular structure of bacterial plasmids. Bacteriological Reviews 36, 361-405.

Clowes, R. C. \& HAYEs, W. (1968). Experiments in Microbial Genetics. Oxford and Edinburgh: Blackwell Scientific Publications.

Clowes, R. C. \& Moody, E. E. M. (1966). Chromosomal transfer from 'Recombination-deficient' strains of Escherichia coli K-1 2. Genetics 53, 717-726.

CoEtzeE, J. N. (196r). Lysogenic conversion in the genus Proteus. Nature, London r89, 946-947.

Coetzee, J. N. (1972). Genetics of the Proteus group. Annual Review of Microbiology 26, $23-54$.

CoetzeE, J. N. (1974). Properties of Proteus and Providence strains harbouring recombinant plasmids between P-lac RIdrd19 or R447b. Journal of General Microbiology 80, I19-130.

Coetzee, J. N., Datta, N., Hedges, R. W. \& Appelbaum, P. C. (1973). Transduction of R factors in Proteus mirabilis and P. rettgeri. Journal of General Microbiology 76, 355-368.

Coetzee, H. L., De Klerk, H. C. \& Coetzee, J. N. (1968). Bacteriophage-tail-like particles associated with intra-species killing of Proteus vulgaris. Journal of General Virology 2, 29-36.

Coetzee, J. N. \& SACKs, T. G. (1960). Transduction of streptomycin resistance in Proteus mirabilis. Journal of General Microbiology 23, 445-455.

CoetzeE, J. N. \& SMIT, J. A. (1969). Restriction of a transducing bacteriophage in a strain of Proteus mirabilis. Journal of General Virology 4, 593-607.

Coetzee, J. N. \& Smit, J. A. (1970). Properties of Proteus mirabilis phage I 3 vir. Journal of General Virology 9 , 247-249.

Coetzee, J. N., Smit, J. A. \& Prozesky, O. W. (1966). Properties of Providence and Proteus morganii transducing phages. Journal of General Microbiology 44, 167-176.

Cooke, M. \& MeYNell, E. (1969). Chromosomal transfer mediated by de-repressed R factors in $\mathrm{F}^{-}$Escherichia coli K12. Genetical Research 14, 79-87.

DE HAAN, P. G. \& Gross, J. D. (1962). Transfer delay and chromosome withdrawal during conjugation in Escherichia coli. Genetical Research 3, $25 \mathrm{I}-272$.

Dienes, L. (1946). Reproductive processes in Proteus cultures. Proceedings of the Society for Experimental Biology and Medicine 63, 265-270. 
DIENES, L. (1947). Further observations on the reproduction of bacilli from large bodies in Proteus cultures. Proceedings of the Society for Experimental Biology and Medicine 66, 97-98.

Edwards, S. \& Meynell, G. G. (1969). I sex factors and chromosomal recombination in Salmonella typhimurium. Genetical Research $13,321-323$.

EvenChiK, Z., STACEY, K. A. \& HAYeS, W. (1969). Ultraviolet induction of chromosome transfer by autonomous sex factors in Escherichia coli. Journal of General Microbiology 56, I-14.

Falkow, S., Wohlhieter, J. A., Crtarella, R. V. \& Baron, L. S. (1964). Transfer of episomic elements to Proteus. Journal of Bacteriology 88, I598-160I.

Grabow, W. O. K. (1972a). Transduction analysis of methionine genes in Proteus mirabilis. Heredity 28, I29-139.

Grabow, W. O. K. (1972b). Transductional analysis of cysteine mutants in Proteus mirabilis. Journal of General Microbiology 70, 77-85.

Grabow, W. O. K. \& SmIT, J. A. (1967). Methonine synthesis in Proteus mirabilis. Journal of General Microbiology 46, 47-57.

Haapala, D. K. \& Falkow, S. (1971). Physical studies of the drug resistance transfer factor in Proteus. Journal of Bacteriology ro6, 294-295.

HAYES, W. (1952). Recombination in Bact. coli KI2: unidirectional transfer of genetic material. Nature, London 169, I $18-119$.

HAYES, W. (1953). Observations on a transmissible agent determining sexual differentiation in Bacterium coli. Journal of General Microbiology 8, 72-88.

Hirota, Y., FujI, T. \& Nishimura, Y. (1966). Loss and repair of conjugal fertility and infectivity of the resistance factor and sex factor in Escherichia coli. Journal of Bacteriology 91, I 298-1304.

Holloway, B. W. \& FARGIE, B. (1960). Fertility factors and genetic linkage in Pseudomonas aeruginosa. Journal of Bacteriology 80, 362-368.

Hutchinson, W. G. \& Medill, M. A. (1954). The isolation of Proteus mutants and their use in recombination experiments. Bacteriological Proceedings, 40-4I.

Hutchinson, W. G., \& STEMPen, H. (1954). In Sex in Microorganisms, pp. 29-4I. Edited by D. H. Wenrich, I. F. Lewis and J. R. Raper. Washington: American Association for the Advancement of Science.

JACOB, F. \& Wollman, E. L. (1956). Recombination genetique et mutants de fertilité chez Escherichia coli. Comptes rendus hebdomadaire des séances de l'Académie des sciences 242, 303-306.

Krizsanovich, K. (1973). Cryptic lysogeny in Proteus mirabilis. Journal of General Virology 19, 31 I-320.

Kvirtingen, J. (1953). Studies of the life-cycle of Proteus Hauser part 3. Acta pathologica et microbiologica scandinavica 32, $170-186$.

LoUTIT, J. S. (1969). Investigation of the mating system of Pseudomonas aeruginosa strain I. IV. Mapping of distal markers. Genetical Research 13, 9I-98.

Loutit, J. S., Marinus, M. G. \& Pearce, L. E. (1968). Investigation of the mating system of Pseudomonas aeruginosa strain I. III. Kinetic studies on the transfer of the sex factor (FP). Genetical Research 21, 139-145.

Loutit, J. S., Pearce, L. E. \& Marinus, M. G. (1968). Investigation of the mating system of Pseudomonas aeruginosa strain I. I. Kinetic studies. Genetical Research 12, 29-36.

MaCFarRen, A. C. \& Clowes, R. C. (1967). A comparative study of two F-like colicin factors, ColV2 and $\mathrm{ColV}_{3}$, in Escherichia coli K-I2. Journal of Bacteriology 94, 365-377.

MEYNELL, E. \& COOKE, M. (1969). Repressor-minus and operator-constitutive de-repressed mutants of F-like $\mathrm{R}$ factors. Their effect on chromosomal transfer by HfrC. Genetical Research 14, 309-313.

Meynell, E. \& DatTA, N. (1967). Mutant drug resistance factors of high transmissibility. Nature, London $214,885-887$.

Meynell, E. \& EwINs, A. (1973). Effect on exclusion of alterations to the sex pilus. Journal of Bacteriology II3, 7I-75.

Moody, E. E. M. \& HAYES, W. (1972). Chromosome transfer by autonomous transmissible plasmids: the role of the bacterial recombination (rec) system. Journal of Bacteriology III, 80-85.

Moody, E. E. M. \& RUNGE, R. (1972). The integration of autonomous transmissible plasmids into the chromosome of Escherichia coli K12. Genetical Research 19, 18I-186.

Niemand, J. G. (197I). A classification of bacteriocins active on a strain of Proteus mirabilis. M.Sc. thesis, University of Pretoria, South Africa.

Nishimura, A., Nishimura, Y. \& Caro, L. (1973). Isolation of Hfr strains from $\mathbf{R}^{+}$and ColV2 strains of Escherichia coli and derivation of an R'lac factor by transduction. Journal of Bacteriology 116 , I $107-1112$. 
Ozeki, H. \& Howarth, S. (1961). Colicine factors as fertility factors in bacteria. Salmonella typhimurium strain LT2. Nature, London 190, 986-988.

Pearce, L. E. \& Meynell, E. (1968). Specific chromosomal affinity of a resistance factor. Journal of General Microbiology 50, I59-I 72.

Pemberton, J. M. \& Holloway, B. W. (1972). Chromosome mapping in Pseudomonas aeruginosa. Genetical Research 19, 251-260.

Pemberton, J. M. \& Holloway, B. W. (1973). A new sex factor of Pseudomonas aeruginosa. Genetical Research 2r, 263-272.

Pittard, J. \& Adelberg, E. A. (I963). Gene transfer by $\mathrm{F}^{\prime}$ strains of Escherichia coli $\mathrm{K}-\mathrm{I}$ 2. II. Interaction between F-merogenote and chromosome during transfer. Journal of Bacteriology 85, 1402-1408.

Pittard, J., Loutit, J. S. \& AdelberG, E. A. (1963). Gene transfer by F' strains of Escherichia coli K-I 2. I. Delay in initiation of chromosome transfer. Journal of Bacteriology 85, 1934-I40I .

Prozesky, O. W. (1968). Transductional analysis of arginineless mutants in Proteus mirabilis. Journal of General Microbiology 54, 127-143.

Prozesky, O. W., Grabow, W. O. K., Van der Merwe, S. \& Coetzee, J. N. (1973). Arginine gene clusters in the Proteus-Providence group. Journal of General Microbiology 77, 237-240.

Stanisch, V. \& Holloway, B. W. (1969). Conjugation in Pseudomonas aeruginosa. Genetics 6r, $327-339$.

Stanisch, V. A. \& Holloway, B. A. (1971). Chromosome transfer in Pseudomonas aeruginosa mediated by $\mathbf{R}$ factors. Genetical Research $17, \mathrm{I} 69-172$.

Stempen, H. \& Hutchinson, W. G. (I95I). The formation and development of large bodies in Proteus vulgaris ox-19. I. Bright phase contrast observations of living bacteria. Journal of Bacteriology 6r, 32 X335 .

Sugino, Y., \& Hirota, Y. (1962). Conjugal fertility associated with resistance factor R in Escherichia coli. Journal of Bacteriology 84, 902-910.

Van Rensburg, A. J. (1970). Studies on Proteus and Providence spheroplasts, L-forms and bacteriophage nucleic acids. M.D. thesis, University of Pretoria, South Africa.

Van Rensburg, A. J. (I97I). Genetic transformation in Proteus mirabilis. Journal of General Microbiology 66, 2 I 5-2I9.

WatanABE, T. \& OGATA, C. (1966). Episomic-mediated transfer of drug resistance in Enterobacteriaceae. IX. Recombination of an R factor with F. Journal of Bacteriology 9r, 43-50.

Wohlhieter, J. A., Falkow, S., Citarella, R. V. \& Baron, L. S. (I964). Characterization of DNA from a Proteus strain harboring an episome. Journal of Molecular Biology 9, 576-588. 